\title{
Effects of chronic dietary fructose with and without copper supplementation on glycaemic control, adiposity, insulin binding to adipocytes and glomerular basement membrane thickness in normal rats
}

\author{
BY SALWA W. RIZKALLA ${ }^{1}$, JOSETTE BOILLOT ${ }^{1}$, VIVIANNE TRICOTTET ${ }^{2}$, \\ ANNE-MARIE FONTVIEILLE ${ }^{1}$, JING LUO ${ }^{1}$, JEAN-LOUP SALZMAN ${ }^{2}$, \\ JEAN-PIERRE CAMILLERI' AND GÉRARD SLAMA*1 \\ ${ }^{1}$ Department of Diabetes (Inserm U34I), Hotel Dieu Hospital, Paris, France and ${ }^{2}$ Department of \\ Pathological Anatomy, Broussais Hospital, Paris, France
}

(Received 24 March 1992 - Accepted 5 August 1992)

\begin{abstract}
Sucrose feeding over a long period has been reported to induce glomerular basement membrane (GBM) thickening and insulin resistance in normal rats. These effects are attributed to the fructose moiety of the sucrose molecule, to $\mathrm{Cu}$ deprivation or both. Consequently, our aim was to evaluate the long-term effects of fructose feeding with normal or high amounts of $\mathrm{Cu}$ on body weight, plasma lipids, blood glucose regulation, GBM thickening and insulin binding to adipocytes. Four groups of eight Sprague-Dawley rats were fed for 10 weeks on a diet containing $570 \mathrm{~g}$ carbohydrate $/ \mathrm{kg}$ supplied either as starch (S), dextrose (D), fructose (F) or fructose-starch $(1: 1, w / w ; F S)$, and an adequate amount of $\mathrm{Cu}(12 \mu \mathrm{g} \mathrm{Cu} / \mathrm{g}$ diet). A fifth group was fed on diet $\mathrm{F}$ supplemented with $24 \mu \mathrm{g} \mathrm{Cu} / \mathrm{g}$ diet (FCu). After 10 weeks the epididymal adipose tissue and kidney weights expressed per $100 \mathrm{~g}$ body weight (relative weight) were heaviest in the F and FCu groups $(P<0.0001$, ANOVA). The GBM thickness was within the normal range in the five groups but significantly higher in group $D(1.95$ (SE 0.04$) \mathrm{nm}$ and lower in group FS (1.79 (SE 0.02) $\mathrm{nm}$ when compared with group $\mathrm{S}(1.85$ (SE 0.03) $\mathrm{nm} ; P<0.05)$. Insulin binding to adipocytes (expressed per cell) was lowest in the F and FCu groups, intermediate in groups D and FS and highest in group $S(P<0.05)$. Fasting plasma insulin level was higher in group $F$ than in the $F C u$ and FS groups $(P<0.05)$, whereas fasting plasma glucose, total cholesterol and triacylglycerol levels remained within the normal range in all groups. We conclude that in normal rats a 10-week fructose-rich diet with an adequate amount of $\mathrm{Cu}$ produced deleterious metabolic effects on adipose tissue, insulin binding to adipocytes, and plasma insulin, but not on GBM thickening even though kidney weight was significantly increased. However, a moderate fructose intake mixed with other sugars did not have adverse effects.
\end{abstract}

Fructose intake: Copper: Insulin binding: Adipose tissue

Fructose is characterized by a partly insulin-independent metabolism and by a moderate hyperglycaemic and insulinogenic effect in man (Crapo et al. 1982; Bantle et al. 1983). This simple sugar is still often credited with a higher sweetening potency than that of sucrose (Schallenberger, 1963), although this property has recently been questioned (Fontvieille $\mathrm{et}$ al. 1989). Because of these advantages and the recent technological advances that have simplified its industrial production, fructose is widely prescribed and used by diabetic subjects (Thorburn et al. 1989a). Fructose utilization has also increased among the general population. However, the metabolic effects of its chronic utilization have not yet been fully established. Fructose was found to increase plasma triacylglycerol levels in predisposed

\footnotetext{
* For reprints.
} 
individuals and in normal and diabetic rats (Zavaroni et al. 1982; Hallfrisch et al. 1983; Bacon et al. 1984). It has also been found to have inhibitory effects on insulin receptors of blood cells (Beck-Nielsen et al. 1980; Rizkalla et al. 1986), which raises the question of whether or not these effects could also be present in target tissues such as adipocytes.

In addition, fructose was found to increase the thickness of the glomerular basement membrane (GBM) in normal rats (Taylor et al. 1980, 1985). Other authors attributed this undesirable effect to the $\mathrm{Cu}$ deficiency in the diets used (Cohen et al. 1982).

Therefore, we decided first to determine whether the chronic consumption of high- or moderate-fructose diets supplemented with an adequate level of $\mathrm{Cu}$ produces either beneficial or detrimental consequences, and second, to establish whether doubling the $\mathrm{Cu}$ level ameliorates the detrimental effects. The effects of these diets were studied on plasma variables in the kidney (function and morphology) and in the epididymal adipose tissue (cellularity, and insulin binding to adipocytes).

\section{MATERIALS AND METHODS \\ Experimental protocol}

Forty male Sprague-Dawley rats aged $21 \mathrm{~d}$ were used. The rats were housed in groups of four in sedentary cages, not allowed to have any form of physical exercise such as running on wheels, and maintained at $24^{\circ}$ with a $12 \mathrm{~h}$ light-dark cycle. The rats were randomized into five groups. The rats in four groups were fed on a powder diet (synthetic diet no. 210; Factory of Rational Alimentation, Villemoisson/Orge, France) containing $570 \mathrm{~g}$ carbohydrate/kg supplied either as corn starch (S; $240 \mathrm{~g}$ amylose and $760 \mathrm{~g}$ amylopectin $/ \mathrm{kg}$ ), dextrose (D), fructose (F), or fructose-starch $(1: 1, w / w ; F S)$ and an adequate amount of copper $(12 \mu \mathrm{g} \mathrm{Cu} / \mathrm{g}$ diet $)$ according to the recommendations of the French National Center for Nutritional and Dietary Research (CNERNA) (Poitier De Courcy et al. 1987). The fifth group was fed on $570 \mathrm{~g}$ fructose $/ \mathrm{kg}$ diet supplemented with twice the amount of $\mathrm{Cu}$ $(24 \mu \mathrm{g} \mathrm{Cu} / \mathrm{g}$ diet $; \mathrm{FCu})$, since it has been reported that diets containing fructose require 2-3 times as much $\mathrm{Cu}$ as those fed on starch (Failla et al. 1988). The other components of the powder diet were $(\mathrm{g} / \mathrm{kg})$ : casein 225 , plant and animal fats 55 (P:S ratio $0 \cdot 67$ ), cellulose 60 , minerals 70 and a balanced mixture of vitamins (Poitier De Courcy et al. 1987). Food intake was measured once per day and body weight once per week.

At week 10 the rats were decapitated after an overnight fast. Blood, epididymal fat and kidneys were removed.

\section{Insulin binding study}

Epididymal adipocytes were isolated using the method of Rodbell (1964). Isolated adipocytes were incubated in duplicate for $60 \mathrm{~min}$ at $24^{\circ}$ (Bolinder et al. 1983) in a final concentration of $40 \mathrm{ml} / 1$ in a Krebs-Ringer-Bicarbonate buffer ( $\mathrm{pH} \mathrm{7.4)} \mathrm{containing} 35 \mathrm{mg}$ bovine serum albumin $/ \mathrm{ml}, 1 \mathrm{mg} \mathrm{D}$-glucose $/ \mathrm{ml}, 0.3 \mathrm{ng}$ mono- ${ }^{125} \mathrm{I}-\left(\mathrm{Tyr} \mathrm{A}_{14}\right)$ insulin, and $0-10^{4} \mathrm{ng}$ unlabelled insulin $/ \mathrm{ml}$. The binding reaction was terminated by adding $10 \mathrm{ml}$ icecold saline $(9 \mathrm{~g} \mathrm{NaCl} / 1)$. The cells were immediately filtered (Cuatrecasas, 1971) and gently washed with another $10 \mathrm{ml}$ ice-cold saline. The steps of saline addition, filtration and second washing take less than $1 \mathrm{~min}$. The filtrates were removed and counted in a gamma counter. The incubation was done at $24^{\circ}$ for $60 \mathrm{~min}$ as it has been demonstrated (Bolinder et al. 1983) that insulin degradation is negligible at this temperature, and that a steady state of insulin binding is reached after $40 \mathrm{~min}$ and maintained for at least $120 \mathrm{~min}$. All these data were corrected for nonspecific binding, which amounted to about $0.4-0.6 \%$ of the total binding, and were expressed as the amount of insulin specifically bound per fat cell. The apparent receptor affinity is the concentration of native insulin required to reduce the 
specific cell-bound fraction of $\left.{ }^{125} \mathrm{I}\right]$ insulin by $50 \%\left(\mathrm{ED}_{50}\right)$. The receptor number was calculated using Scatchard plots (Scatchard, 1949) in which bound and free radioactive insulin levels were plotted as a function of bound hormone for insulin concentrations from 0.01 to $100 \mathrm{ng} / \mathrm{ml}$. Graphic extrapolation of the curves, to obtain their intercepts with the $x$ axis, gave the receptor number.

The actual volume of the adipocytes in the above suspension was measured in duplicate by centrifugation in haematocrit tubes, at $13400 \mathrm{~g}$ for $3 \mathrm{~min}$. The number of adipocytes in the given volume was calculated as total adipocyte fraction volume divided by mean adipocyte volume.

Mean fat-cell size (diameter and volume) was determined using a photographic method according to Lavau et al. (1977); at least 300 cells were photographed for each rat sample. The mean fat-cell volume was calculated with Goldrick's formula (Goldrick, 1967) and the mean fat-cell weight was determined by using triolein density $(0.915)$.

\section{GBM measurements}

For each rat, three small blocks of kidney cortex were taken and immediately fixed in glutaraldehyde solution ( $20 \mathrm{~g} / \mathrm{l})$, followed by osmium fixation, dehydration and embedding in Vestopol (epoxi-resin; Ladd products, Janning, 92 Vanves, France). Two pictures were selected from each block. The full thickness of the GBM was measured on a strictly perpendicular section on at least ten sites of six capillary loops, giving a total of sixty measurements per rat.

\section{Biological analysis}

Plasma insulin was measured, in the same batch, by radioimmunoassay (intra-assay reproducibility, 6\%) using antiserum raised in guinea pigs (kits CIS International, Gif sur Yvette, France) and a standard curve of rat insulin. Plasma glucose was determined by the glucose oxidase (EC 1.1.3.4) method (Beckman Autoanalyser, Fullerton, CA, USA). Plasma cholesterol (Allain et al. 1974) and triacylglycerols (Bucolo \& David, 1973) were also measured.

\section{Statistical analysis}

Overall comparisons between the different diet groups were made using one-way analysis of variance (ANOVA). When a significant $F$ value was obtained for the ANOVA $(P<0 \cdot 05)$ the differences between all pairs of means were tested using Fisher's Least Significance Difference (LSD) procedure. Statistical analysis was performed with Statview $512+$ software (Brainpower Inc., Calabasas, CA, USA). Results are given as mean values with standard errors.

\section{RESULTS}

\section{Body, adipose tissue and kidney weight}

As shown in Fig. 1, body weights were significantly different between weeks 3 and 7 (ANOVA, $P<0.05$ ). Mean values were highest in the group fed on diet $\mathrm{D}$ and lowest in the group fed on diet F. Values for rats fed on diet $F$ were also significantly lower than those of rats fed on diet FCu during weeks 3,4 and 6. When results were expressed as weight gain (Table 1), the rats fed on diets D and FS nearly always gained more weight than those fed on diets $\mathrm{S}, \mathrm{F}$ and $\mathrm{F} / \mathrm{Cu}$. These differences were clearly significant until week 6 , after which this significance started to decline.

Food intake (Table 1) showed a tendency to decrease in group $\mathrm{F}$ and $\mathrm{S}$, but an increase in group D. These variations became significantly different at week 6 . The total food intake per rat during the 10 weeks of the corresponding diet was significantly higher (ANOVA, $P<0.005)$ in the rats fed on diet D $\left(1.8(\right.$ SE 0.03$\left.) \times 10^{4} \mathrm{~kJ}\right)$ than in those fed on diets $\mathrm{S}$ 


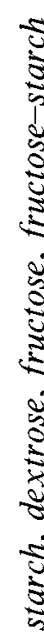

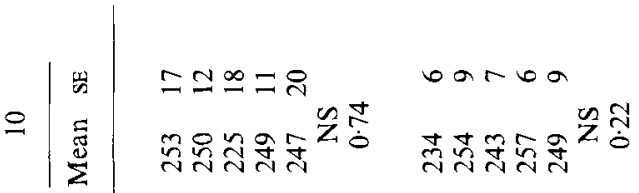

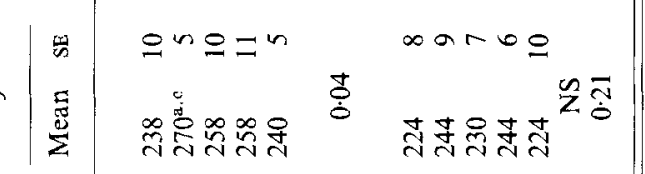

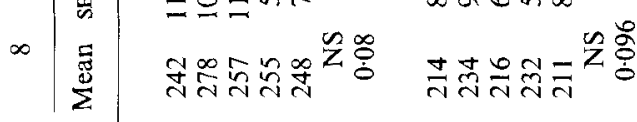

I Dan

ड़

莡

$-\sum_{\Sigma}^{\mathbb{J}}$

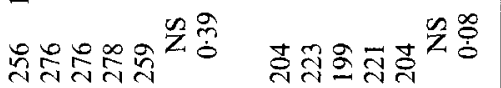

焉

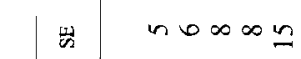

$\infty n \infty \mathrm{m} \sigma$

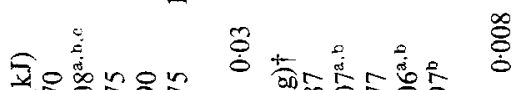

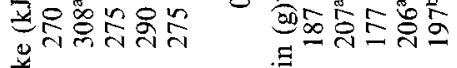

के

0

范

ะั

का 8

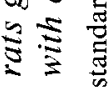

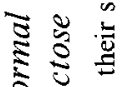

율유은

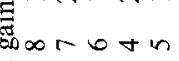

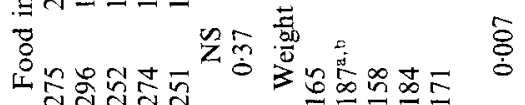

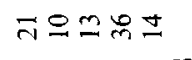

$\infty 000 \mathrm{~m}$

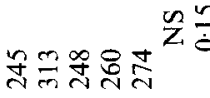

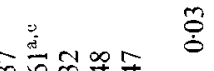

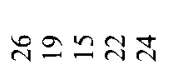

ร $\frac{0}{3}$

$\approx 3$

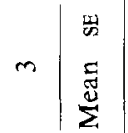

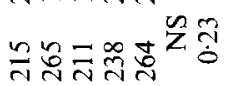

-ำㅁำ

ongun

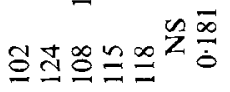

요 $\cong \infty \simeq$

$n+m \forall m$

हे

:

$\stackrel{8}{8}$

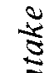

胥

8

.

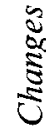

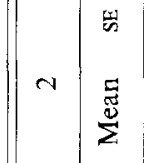

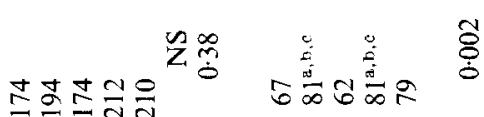

I.

$\Xi ニ \cong m \infty$

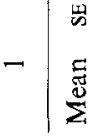

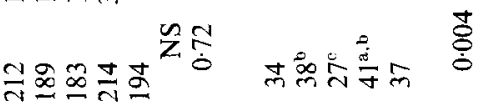

둘 눙

总

$\frac{1}{2}$

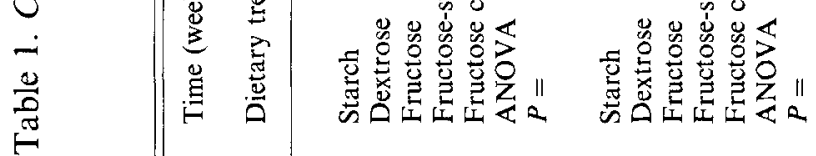


Table 2. Body, kidney and epididymal fat-pad weights, energy efficiency, cellularity of fatpads and fasting plasma creatinine, glucose, insulin and lipid levels of normal rats given diets containing starch, dextrose, fructose, fructose-starch $(1: 1, w / w)$ or fructose with copper* for 10 weeks

(Mean values with their standard errors for eight rats)

\begin{tabular}{|c|c|c|c|c|c|c|c|c|c|c|c|}
\hline \multirow[t]{2}{*}{ Dietary treatment... } & \multicolumn{2}{|c|}{ Starch } & \multicolumn{2}{|c|}{ Dextrose } & \multicolumn{2}{|c|}{ Fructose } & \multicolumn{2}{|c|}{ Fructose-starch } & \multicolumn{2}{|c|}{ Fructose copper } & \multirow[t]{2}{*}{$P$, ANOVA } \\
\hline & Mean & $\mathrm{SE}$ & Mean & $\mathrm{SE}$ & Mean & $\mathrm{SE}$ & Mean & $\mathrm{SE}$ & Mean & $\mathrm{SE}$ & \\
\hline Body wt (Bw; g) & 324 & 6 & 342 & 9 & 330 & 7 & 344 & 6 & 335 & 10 & NS \\
\hline $\begin{array}{l}\text { Energy efficiency } t \\
(\mathrm{~g} / 100 \mathrm{~kJ})\end{array}$ & $1 \cdot 40$ & $0 \cdot 05$ & 1.38 & 0.07 & 1.47 & 0.04 & 1.46 & 0.05 & 1.42 & 0.08 & NS \\
\hline \multicolumn{12}{|l|}{ Fat-pad wt $(\mathrm{g})+$ : } \\
\hline Absolute & $3 \cdot 5$ & $0 \cdot 2$ & $4 \cdot 0^{b}$ & $0 \cdot 2$ & $4 \cdot 4^{a, b}$ & $0 \cdot 3$ & $2 \cdot 9$ & 0.2 & $4 \cdot 7^{\mathrm{a}, \mathrm{b}}$ & 0.5 & $<0.0004$ \\
\hline Relative $(/ 100 \mathrm{~g} \mathrm{Bw})$ & $1 \cdot 07$ & 0.05 & $1 \cdot 18^{\mathrm{b}}$ & 0.04 & $1 \cdot 31^{\mathrm{a}, \mathrm{h}}$ & 0.08 & $0 \cdot 83$ & 0.07 & $1 \cdot 35^{\mathrm{a}, \mathrm{b}}$ & $0 \cdot 10$ & $<0.0001$ \\
\hline $\begin{array}{l}\text { Adipocyte number } \\
\left(\times 10^{6}\right)\end{array}$ & $13 \cdot 8$ & $1 \cdot 3$ & $15 \cdot 1$ & $1 \cdot 4$ & $16 \cdot 2^{\mathrm{b}}$ & 0.8 & $11 \cdot 2$ & $0 \cdot 9$ & $17 \cdot 5^{\mathrm{b}}$ & $2 \cdot 3$ & $<0.01$ \\
\hline $\begin{array}{l}\text { Adiporyte diameter } \\
(\mu \mathrm{m})\end{array}$ & $80 \cdot 0$ & $3 \cdot 4$ & $81 \cdot 6$ & $2 \cdot 0$ & $78 \cdot 9$ & $1 \cdot 2$ & $78 \cdot 3$ & $1 \cdot 1$ & $82 \cdot 3$ & $3 \cdot 2$ & NS \\
\hline \multicolumn{12}{|l|}{ Kidney wt $(\mathrm{g}) \pm$ : } \\
\hline Absolute & $2-06$ & 0.03 & $2 \cdot 21$ & 0.04 & $2 \cdot 44^{\mathrm{a} .}$ & 0.03 & $2 \cdot 33$ & 0.04 & $2 \cdot 57^{\mathrm{a} \cdot \mathrm{b}, \mathrm{c}}$ & 0.06 & $<0.001$ \\
\hline Relative $(/ 100 \mathrm{~g} \mathrm{Bw})$ & 0.64 & 0.01 & 0.65 & 0.01 & $0.74^{a, b, e}$ & 0.01 & 0.67 & 0.02 & $0.77^{\mathrm{a}, \mathrm{b}, \mathrm{c}}$ & 0.02 & $<0.0001$ \\
\hline $\begin{array}{l}\text { Plasma creatinine } \\
(\mu \mathrm{mol} / \mathrm{l})\end{array}$ & $66 \cdot 6$ & $3 \cdot 4$ & $64 \cdot 9$ & $1 \cdot 9$ & $63 \cdot 3$ & $2 \cdot 1$ & $58 \cdot 7$ & $1 \cdot 8$ & $58 \cdot 1$ & $1 \cdot 3$ & NS \\
\hline $\begin{array}{l}\text { Plasma glucose } \\
(\mathrm{mmol} / \mathrm{l})\end{array}$ & $5 \cdot 6$ & 0.1 & $5 \cdot 3$ & $0 \cdot 1$ & $5 \cdot 6$ & 0.2 & $5 \cdot 4$ & $0 \cdot 1$ & $5 \cdot 6$ & $0 \cdot 2$ & NS \\
\hline $\begin{array}{l}\text { Plasma insulin } \\
(\mu \mathrm{U} / \mathrm{l})\end{array}$ & $40 \cdot 1$ & $3 \cdot 4$ & $39 \cdot 8$ & $3 \cdot 6$ & $50 \cdot 5^{b, d}$ & $8 \cdot 4$ & $29 \cdot 4$ & $2 \cdot 3$ & $34 \cdot 9$ & 4.6 & $<0.05$ \\
\hline $\begin{array}{l}\text { Plasma cholesterol } \\
(\mathrm{mmol} / \mathrm{l})\end{array}$ & 1.95 & $0 \cdot 26$ & 1.82 & 0.28 & 2.04 & $0 \cdot 28$ & $2 \cdot 09$ & 0.36 & $2 \cdot 43$ & 0.47 & NS \\
\hline $\begin{array}{l}\text { Plasma triacylglycerol } \\
(\mathrm{mmol} / \mathrm{l})\end{array}$ & $1 \cdot 14$ & 0.15 & 0.94 & 0.09 & $1 \cdot 10$ & 0.14 & 0.85 & 0.08 & 1.02 & $0 \cdot 14$ & NS \\
\hline
\end{tabular}

${ }^{a}$ Significantly different from starch; ${ }^{b}$ significantly different from fructose-starch; ${ }^{c}$ significantly different from dextrose; ${ }^{a}$ significantly different from fructose copper $(P<0.05)$.

* For details of diets, see p. 200.

$\dagger$ Energy efficiency is expressed as weight gain at week 10; total energy intake ratio.

$\$$ Kidney and fat-pad weights represent the weight of the two kidneys or the two fat pads in the eight rats.

$\left(1.6(\mathrm{SE} 0.04) \times 10^{4} \mathrm{~kJ}\right), \quad \mathrm{F}\left(1.6(\mathrm{SE} 0.02) \times 10^{4} \mathrm{~kJ}\right), \quad \mathrm{FS}\left(1.7(\mathrm{SE} 0.04) \times 10^{4} \mathrm{~kJ}\right)$ and $\mathrm{FCu}$ $\left(1.7(\mathrm{SE} 0.05) \times 10^{4} \mathrm{~kJ}\right)$. However, when the total energy intake was related to weight gain to calculate the energy efficiency, no significant difference was observed among the groups as shown in Table 2.

Fig. 1 and Tables 1 and 2 show that at the end of week 10 neither body weights nor weight gain were different, whereas epididymal fat pads increased in weight in groups $\mathrm{F}$ and $\mathrm{FCu}$ compared with groups $\mathrm{S}$ and FS (ANOVA, $P<0.0004$ ). When the results were expressed per $100 \mathrm{~g}$ body weight (relative weight), groups $\mathrm{F}$ and $\mathrm{FCu}$ remained higher than groups $\mathrm{S}$ and FS (ANOVA, $P<0.0001$ ).

Fat deposition in the groups fed on fructose-rich diets was related to an increase (ANOVA, $P<0.05$ ) in the number of adipocytes (groups $\mathrm{F}$ and $\mathrm{FCu} v$. group FS) rather than to an increase in cell volume as shown in Table 1 .

The kidneys increased in weight in all the fructose-fed groups ( $\mathrm{F}, \mathrm{FCu}, \mathrm{FS})$ compared with group S (ANOVA, $P<0.0001$ ), but only in the high fructose groups ( $\mathrm{F}$ and $\mathrm{FCu}$ ) compared with group D. However, when kidney weight was expressed per $100 \mathrm{~g}$ body weight, kidneys of rats fed on the high-fructose diets $(\mathrm{F}, \mathrm{FCu})$ were heavier than those of groups S, D and FS. 


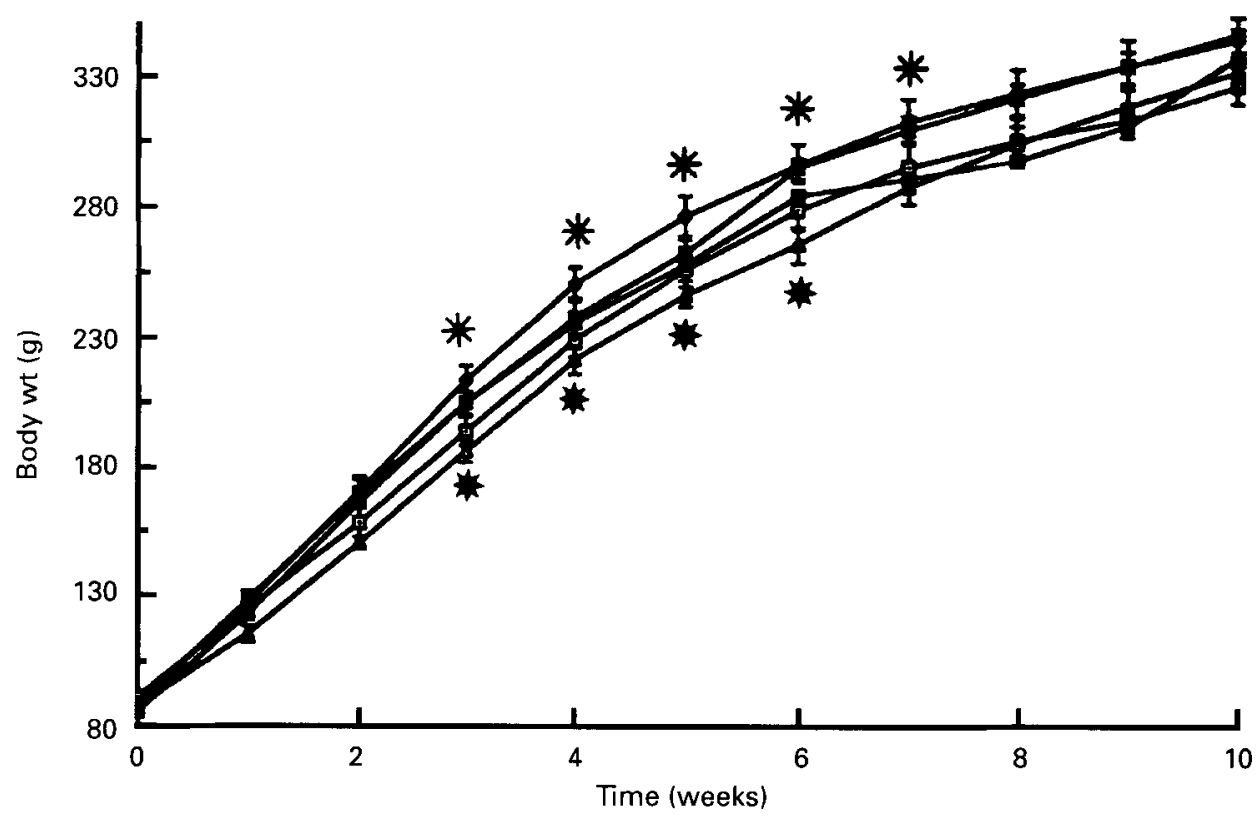

Fig. 1. Changes in body weight during the 10-week feeding period in the starch $(\square)$, dextrose $(\bullet)$, fructose $(\triangle)$, fructose - starch $(X)$ and fructose copper $(\boldsymbol{\square})$ groups. Significant differences, F v. D (ANOVA $* P<0 \cdot 05$ ), F $v$. $\mathrm{FCu}(\mathrm{ANOVA} * P<0.05)$.

\section{GBM thickness}

GBM thickness was strictly within the normal range in all five groups, but significantly higher in group D $(1.95(\mathrm{SE} 0.04) \mathrm{nm}$, ANOVA, $P<0.05)$ than in groups FS $(1.79($ SE 0.02$) \mathrm{nm}), \mathrm{S}(1.85(\mathrm{SE} 0.03 \mathrm{~nm}), \mathrm{F}(1.81(\mathrm{SE} 0.03) \mathrm{nm})$ and $\mathrm{FCu}(1.83($ SE 0.04$) \mathrm{nm})$. Therefore, GBM in the groups fed on fructose-rich diets was comparable to the GBM thickness in the control group (S).

\section{Insulin binding to epididymal adipocytes}

As shown in Fig. $2 a$, insulin binding to adipocytes was lower (ANOVA, $P<0.05$ ) in the groups fed on diets $\mathrm{F}(2 \cdot 2$ (SE 0.3$) \% / 10^{5}$ cells) and FCu $\left(1.9(\mathrm{SE} 0.4) \% / 10^{5}\right.$ cells) than in those fed on diets S $(3.9$ (SE 0.4$) \% / 10^{5}$ cells) and D $(3.4$ (SE 0.34$) \% / 10^{5}$ cells). This was accompanied by a decrease in receptor number (Fig. $2 b$ ). There was no correlation between insulin binding to adipocytes and plasma insulin levels.

\section{Plasma variables}

Table 1 shows that fasting plasma insulin increased in group F compared with groups FS and FCu $(P<0 \cdot 05)$. Plasma glucose, total cholesterol, triacylglycerol and creatinine levels remained within the normal range in all the groups, without any significant difference.

\section{DISCUSSION}

A high-fructose diet $(570 \mathrm{~g} / \mathrm{kg})$ in the present study led to delayed body weight gain and a decrease in food intake during the first 6 weeks, which confirms our previous findings (Rizkalla et al. 1990) and those of Bellomo et al. (1987). However, these differences were no longer present at week 10 . 

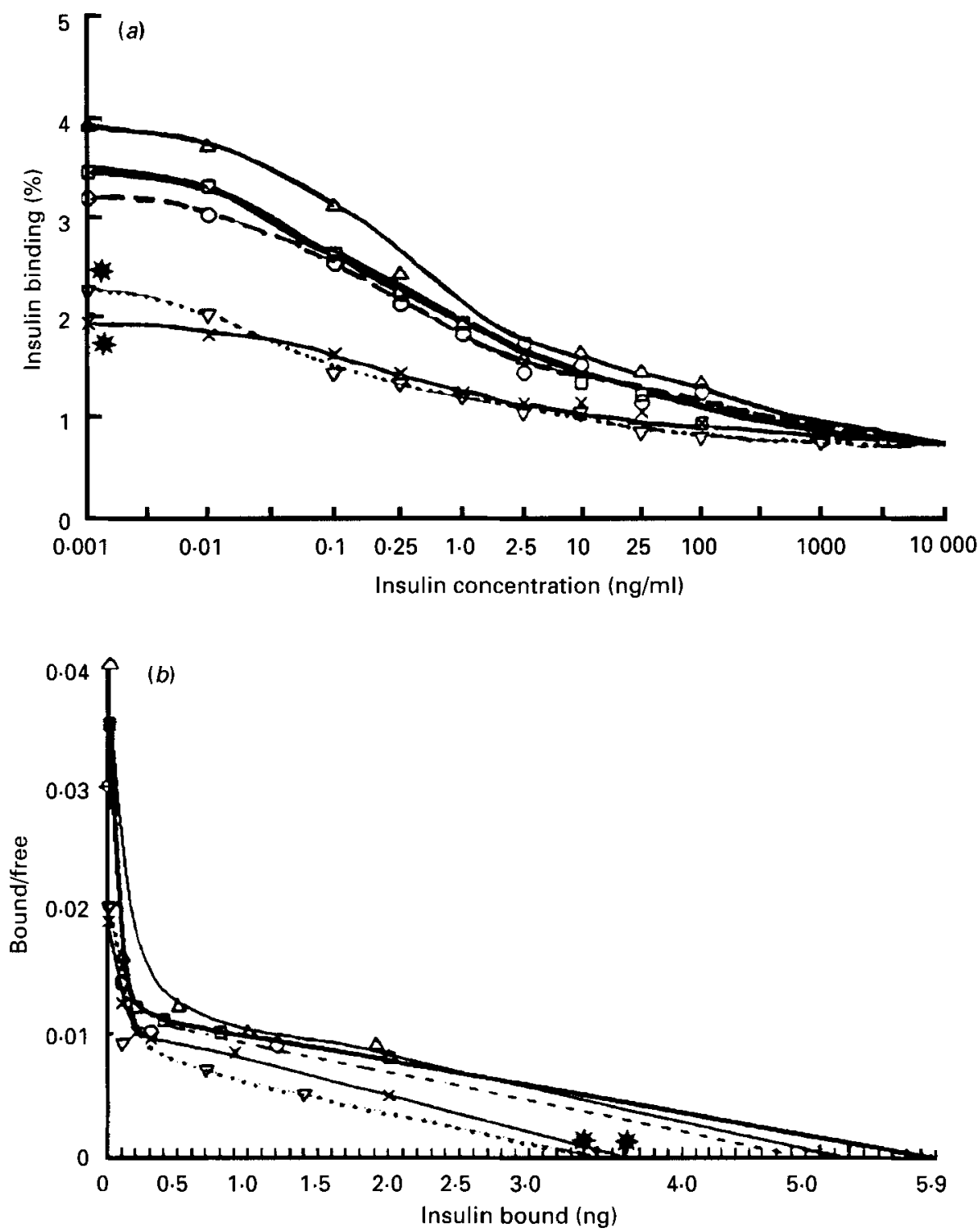

Fig. 2. (a) Insulin binding to adipocytes. Competition inhibition curves, in which the percentage of total radioactivity specifically bound was plotted as a function of insulin concentration, after 10 weeks of starch $\left(-\triangle^{-}\right)$, dextrose (- $\square-$ ), fructose (--- $\nabla---)$, fructose-starch (--- ---$)$ or fructose copper $(-X-)$ diets (results expressed per $10^{5}$ cells); (b) Scatchard plots of the competition curves in which bound and free radioactive insulin was plotted as a function of bound hormone for total insulin concentration from 0.01-100 ng/ml. The Scatchard plots are a curve-fitting program based on the negative cooperativity model (De Meyts \& Roth, 1975). The maximum insulin binding $(\%)$ was significantly lower in groups $\mathrm{F}$ and $\mathrm{FCu} v$. groups $\mathrm{S}$ and $\mathrm{D}$ (ANOVA, $* P<0.05$ ).

At week 10, in all fructose-fed groups, an increase in kidney weight was observed. This finding has often been observed even after a shorter period (Bellomo et al. 1987), or after a similar (Koh et al. 1985) or a longer period (Boot-Handford \& Health, 1981) than that of the present study. This finding could be related to an increase of the glycogen content, since it has been shown that fructose, at least in the liver, increases glycogen synthesis more 
than glucose does (Niewoehner et al. 1984). However, it was the total protein content that increased in the high fructose-fed rats in the present study (results not shown).

The pertinent finding, after 10 weeks of fructose feeding, was the absence of thickening in the GBM, and even a decrease in GBM thickening was found in rats fed on moderate amounts of fructose when compared to those fed on starch or dextrose. Our results are in contradiction with those of Taylor et al. (1985) who demonstrated in young adult Sprague-Dawley rats that a diet containing $550 \mathrm{~g}$ fructose $/ \mathrm{kg}$ (compared with $550 \mathrm{~g}$ glucose $/ \mathrm{kg}$ diet), with $200 \mathrm{~g}$ butter $/ \mathrm{kg}$ produced a thickening in the lamina densa of the GBM after 8 weeks. This thickening further increased after 16 weeks with a considerably expanded mesangium. The absence of any increase in the thickening of GBM in our experiment could be explained by the low-fat content and/or the sufficient amount of $\mathrm{Cu}$ ( $12 \mu \mathrm{g} / \mathrm{g}$ diet) in our experimental diets, which was higher than those recommended by the American Institute of Nutrition (1977). There is no relevant reference in the literature concerning the effect of a low-fat diet on GBM thickness. However, studies over the past 5 years have clearly demonstrated that the type of dietary carbohydrate used affects the consequences of dietary $\mathrm{Cu}$ deficiency in young male rats. Recently Failla et al. (1988) reported that rats which were fed on diets containing fructose required 2-3-fold more dietary $\mathrm{Cu}(2-10 \mu \mathrm{g} \mathrm{Cu} / \mathrm{g}$ food instead of $1-5 \mu \mathrm{g} \mathrm{Cu} / \mathrm{g})$ than those fed on starch, in order to maintain control levels of $\mathrm{Cu}$ in the tissues and to generate a normal humoral immune response. The observed $\mathrm{Cu}$ deficiency from a fructose diet was reported to be a result of impaired $\mathrm{Cu}$ absorption through the small intestine and, to a greater extent, to an increase in the utilization of $\mathrm{Cu}$ (Fields et al. 1986). Another possible explanation for GBM thickening is that the metabolic pathway of fructose sometimes deviates resulting in sorbitol accumulation which causes cellular damage. Recently Bellomo et al. (1987) and Fields et al. (1990) found that prolonged fructose feeding leads to sorbitol accumulation in the kidneys because of the increased flux of glucose through the polyol pathway. This sorbitol is also a strong tissue chelator of $\mathrm{Cu}$, with which it forms a stable complex. Thus, the presence of high amounts of $\mathrm{Cu}(12 \mu \mathrm{g} / \mathrm{g})$ in our experimental diets may have counterregulated the possible damaging effects of fructose, and the production of sorbitol, with regard to GBM thickening. The high-level Cu supplementation $(24 \mu \mathrm{g} / \mathrm{g})$ had no additional beneficial effects. In other words, there seems to be a level above which $\mathrm{Cu}$ has no additional protective effects.

The supplementation with $\mathrm{Cu}$, however, has no protective effects on either epididymal fat-pad weight or on insulin binding to adipocytes. In the present study a high-fructose diet was found to increase the epididymal adipose tissue weight, in spite of the known fructoseinduced decrease in adipose tissue lipogenesis (Blakely et al. 1987) and also, to some extent, lipoprotein lipase activity in this tissue. The results we found with a high-fructose diet are in agreement with others (Koh et al. 1985). This increase in weight was due to hyperplasia (increase in the cellularity). A lower amount of fructose $(275 \mathrm{~g} / \mathrm{kg})$, however, decreased epididymal tissue weight. The mechanism underlying this phenomenon is unknown.

The decrease in insulin binding to adipocytes in rats which were fed on a high- but not a moderate-fructose diet for 10 weeks, as shown in the present study, confirms previous results in non-target cells i.e. erythrocytes and monocytes. Previously we found (Rizkalla et al. 1986) that the presence of small amounts of fructose (as a sole source of carbohydrate) in a very low energy diet $(2 \cdot 1 \mathrm{MJ}(500 \mathrm{kcal}) / \mathrm{d})$ given to obese patients inhibits the expected increase in erythrocyte insulin receptors normally induced by this type of diet. This effect was not detected when subjects were fed on equal amounts of glucose or galactose. Furthermore, in normal weight subjects Beck-Nielsen et al. (1980) reported that a 1-week fructose-rich diet (usual spontaneous diet $+250 \mathrm{~g}$ fructose/d) decreases insulin binding and insulin sensitivity. Moderate fructose feeding, however, in type 2 diabetic subjects has no 
deleterious effects on insulin binding to erythrocytes or adipocytes after $14 \mathrm{~d}$ (Crapo et al. 1986) or 2 months (Grigoresco et al. 1988).

The decrease in insulin binding to adipocytes in the present study might contribute to the fructose-induced in vivo insulin resistance reported by others (Reiser \& Hallfrisch, 1977; Thorburn et al. 1989b). The mechanisms by which fructose may decrease insulin binding are not well defined. Many hypotheses have been proposed: changes in intracellular ATP and cyclic AMP (Hue, 1975; Thomopoulos et al. 1977; Miller, 1978; Trischitta et al. 1984; Kahn et al. 1985); elevated plasma insulin (Olefsky \& Saekow, 1978); or plasma lipids leading to alterations in the physical or chemical nature of membrane lipids (Gould \& Ginsberg, 1985). Whatever the mechanism may be, from the present study we cannot confirm if this is due to the observed hyperinsulinaemia, to other factors, or both.

Another surprising result in our study was the absence of hypertriacylglycerolaemia which is in contradiction to the results of most of the authors using Sprague-Dawley rats (Zavaroni et al. 1982; Bacon et al. 1984). This difference in the results might be due to adaptive mechanisms after chronic fructose feeding. Three studies (Vrana et al. 1976; Sheorain et al. 1980; Lombardo et al. 1983) in which female Swiss mice were fed on a $700 \mathrm{~g}$ sucrose $/ \mathrm{kg}$ diet reported an initial rise in serum triacylglycerols, after 3-25 d, that returned to normal values after prolonged exposure (32-45 d). This adaptation could also be true for rats fed on a fructose diet, since previous studies have reported an increase in triacylglycerols after 1-4-week study periods (Zavaroni et al. 1982; Bacon et al. 1984) but not after 9 or 10 weeks (Bellomo et al. 1987). Alternatively, the absence of hypertriacylglycerolaemia in our study might simply be due to the fact that in our experimental design the rats were fasted for about $12 \mathrm{~h}$ which might mask the otherwise prolonged postprandial hypertriacylglycerolaemia. In our laboratory (Luo et al. 1992) we found hypertriacylglycerolaemia when rats were studied in the fed state. Our results are consistent with some, but not all, investigators who have found hypertriacylglycerolaemia in rats fasted for no more than $6 \mathrm{~h}$ (Sleder et al. 1980; Zavaroni et al. 1982; Bacon et al. 1984) but not in those which have fasted for $12 \mathrm{~h}$ (Bellomo et al. 1987). However, Blakely et al. (1987) found hypertriacylglycerolaemia in Wistar rats fasted for 12-14 h after 11 weeks of feeding fructose $(270 \mathrm{~g} / \mathrm{kg}$ diet) which is in contradiction to our results. This difference could be due to the fact that Blakely et al. (1987) used Wistar rats that were housed individually and, thus, were heavier $(450 \mathrm{~g})$ at the end of the nutritional period than our rats $(350 \mathrm{~g})$ that were Sprague-Dawley rats housed in groups of four. The differences in race and body weight might be implicated in the absence or presence of hypertriacylglycerolaemia.

We conclude first that feeding normal rats on a fructose diet $(570 \mathrm{~g} / \mathrm{kg})$ containing $12 \mu \mathrm{g}$ $\mathrm{Cu} / \mathrm{g}$ diet over 10 weeks resulted in deleterious effects on kidney and epididymal adipose tissue weights, insulin binding to adipocytes and fasting plasma insulin. It did not, however, alter the $12 \mathrm{~h}$ fasting plasma glucose or triacylglycerol levels, nor increase GBM thickness. Second, when fructose represented half the amount of carbohydrate in the diet, no adverse effects could be detected. Third, doubling the amount of $\mathrm{Cu}$ in the fructose diet brought only a beneficial effect on fasting plasma insulin. Although we cannot extrapolate results in rats to humans, care should be taken when using a high-fructose diet even with adequate $\mathrm{Cu}$ levels. Moderate-fructose diets, however, are unlikely to have adverse effects.

We thank Pr B. Guy-Grand for agreeing to measure plasma lipids in his laboratory, and Mrs M. Lavau for permitting us to elaborate fat cell size measurements in her laboratory. We also thank Dr G. Rosselin for kindly providing porcine mono- ${ }^{125} \mathrm{I}-\left(\mathrm{Tyr} \mathrm{A}_{14}\right)$ insulin and Roquette Frères for their fructose gift. We gratefully acknowledge Mrs F. Bruzzo and Mrs N. Desplanque for their technical assistance. 
This work was supported by grants from the National Institute of Scientific and Medical Research (INSERM no. 863387E) and from the Pierre and Marie Curie University.

\section{REFERENCES}

Allain, C. C., Poon, L. S., Chan, C. S., Richmond, W. \& Fu, P. C. (1974). Enzymatic determination of total serum cholesterol. Clinical Chemistry 20, 470.

American Institute of Nutrition (1977). Report of the American Institute of the Nutritional Ad Hoc Committee on Standards for Nutritional Studies. Journal of Nutrition 107, 1340-1348.

Bacon, B. R., Park, C. H., Fowell, E. M. \& McLaren, C. E. (1984). Hepatic steatosis in rats fed diets with varying concentrations of sucrose. Fundamental and Applied Toxicology 4, 819-826.

Bantle, J. P., Laine, D. C., Castle, G. W., Thomas, J. W., Hoogwerf, B. J. \& Goetz, F. C. (1983). Postprandial glucose and insulin responses to meals containing different carbohydrates in normal and diabetic subjects. New England Journal of Medicine 309, 7-12.

Beck-Nielsen, H., Pedersen, O. \& Sorensen, N. S. (1980). Impaired cellular insulin binding and insulin sensitivity induced by high-fructose feeding in normal subjects. American Journal of Clinical Nutrition 33, 273-278.

Bellomo, G., Comstack, J. P., Wen, D. \& Hazelwood, R. L. (1987). Prolonged fructose feeding and aldose reductase inhibition: effect on the polyol pathway in kidneys of normal rats (42624). Proceedings of the Society for Experimental Biology and Medicine 186, 348-354.

Blakely, S. R., Akintilo, A. O. \& Pointer, R. H. (1987). Effects of fructose Levamisole and vanadate on insulin action in rat adipose tissue. Journal of Nutrition 117, 559-566.

Bolinder, J., Ostman, J. \& Arner, P. (1983). Influence of aging on insulin receptor binding and metabolic effects of insulin on human adipose tissue. Diabetes 32, 959-964.

Boot-Handford, R. P. \& Health, H. (1981). The effect of dietary fructose and diabetes on the rat kidney. British Journal of Experimental Pathology 62, 398-406.

Bucolo, G. \& David, H. (1973). Quantitative determination of serum triglyceride by the use of enzymes. Clinical Chemistry 19, 476-482.

Cohen, A. M., Tejtelbaum, A., Miller, E., Ben-tor, V., Hirt, R. \& Fields, M. (1982). Effects of copper on carbohydrate metabolism in rats. Israel Journal of Medical Sciences 18, 840-844.

Crapo, P. A., Kolterman, O. G. \& Henry, P. R. (1986). Metabolic consequence of two week fructose feeding in diabetic subjects. Diabetes Care 9, 111-119.

Crapo, P. A., Scarlett, J. A. \& Kolterman, O. G. (1982). Comparison of the metabolic responses to fructose and sucrose sweetened foods. American Joumal of Clinical Nutrition 36, 256-261.

Cuatrecasas, P. (1971). Insulin-receptor interactions in adipose tissue cells: direct measurement and properties. Proceedings of the National Academy of Sciences of the United States of America 68, 1264-1268.

De Meyts, P. \& Roth, J. (1975). Co-operativity in ligand binding: a new graphic analysis. Biophysics Research Communications 66, 1118-1125.

Failla, M. L., Babu, U. \& Seidel, K. E. (1988). Use of immuno-responsiveness to demonstrate that the dietary requirement for copper in young rats is greater with dietary fructose than dietary starch. Journal of Nutrition $118,487-496$

Fields, M., Holbrook, J., Scholfield, D., Smith, J. C. Jr, Reiser, S. \& Los Alamos Medical Group (1986). Effect of fructose or starch on copper-67 absorption and excretion by the rat. Journal of Nutrition 116, 625-632.

Fields, M., Lewis, C. G., Beal, T. \& Scholfield, D. (1990). Copper deficiency in pregnancy: effect on maternal and fetal polyol metabolites. Metabolism 39, 531-537.

Fontvieille, A. M., Faurion, A., Hela1, I., Rizkalla, S. W., Falgon, S., Letanoux, M., Tchobroutsky, G. \& Slama, G. (1989). Relative sweetness of fructose compared with sucrose in healthy and diabetic subjects. Diabetes Care 12, 481-486.

Goldrick, R. B. (1967). Morphological changes in adipocyte timing of fat deposition and mobilization. American Journal of Physiology 212, 777-782.

Gould, R. J. \& Ginsberg, B. H. (1985). Membrane fluidity and membrane receptor function. In Membrane Fluidity in Biology 3, pp. 257-280 [R. C. Aloia and J. M. Boggy, editors]. New York: Academic Press.

Grigoresco, C., Rizkalla, S. W., Halfon, P., Bornet, F., Fontvieille, A. M., Bros, M., Dauchy, F., Tchobroutsky, G. \& Slama, G. (1988). Lack of detectable deleterious effects on metabolic control of daily fructose ingestion for 2 months in NIDDM patients. Diabetes Care 11, 546-550.

Hallfrisch, J., Reiser, S. \& Prather, E. S. (1983). Blood lipid distribution of hyperinsulinemic men consuming three levels of fructose. American Journal of Clinical Nutrition 37, 740-748.

Hue, L. (1975). The metabolism and toxic effects of fructose. In Sugars in Nutrition, pp. 357 [H. L. Sipple and K. W. McNutt, editors]. New York: Academic Press.

Kahn, C. R., White, M. F., Grigorescu, F., Takayama, S., Haring, H. U. \& Cretaz, M. (1985). The insulin receptor protein kinase. In Molecular Basis in Insulin Action, pp. 67-93 [M. P. Czech, editor]. New York: Plenum Press.

Koh, E. T., Mueller, J., Osilesi, O., Knehaus, A. \& Reiser, S. (1985). Effects of fructose feeding on lipid parameters in obese and lean, diabetic and non diabetic Zucker rats. Journal of Nutrition 115, 1274-1284. 
Lavau, M., Susini, C., Knittle, J., Blanchet-Hirst, S. \& Greenwood, M. R. C. (1977). A reliable photomicrographic method for determining fat cell size and number: application for dietary obesity. Proceedings of the Society for Experimental Biology and Medicine 156, 251-256L.

Lombardo, Y. B., Chicco, A., Mocchiutti, N., de Rodi, M. A., Nusimovich, B. \& Gutman, R. (1983). Effect of sucrose diet on insulin secretion in vivo and in vitro and on triglyceride storage and mobilisation of the heart of rats. Hormone and Metabolic Research 15,69-76.

Luo, J., Rizkalla, S. W., Alamowitch, C., Boillot, J., Bruzzo, F., Chevalier, A. \& Slama, G. (1992). Neither dietary fructose, dextrose nor starch modifies in vitro glycerol release by adipocytes from streptozotocin-diabetic rats. Journal of Nutrition 122, 2361-2366.

Miller, T. B. Jr (1978). Cyclic AMP-mediated activation of hepatic glycogenolysis by fructose. Biochimica et Biophysica Acta 540, 151-161.

Niewoehner, C. B., Gilboe, D. P., Nuttall, G. A. \& Nuttal, F. Q. (1984). Metabolic effects of oral fructose in the liver of fasted rats. American Journal of Physiology 247, E505-512.

Olefsky, J. M. \& Saekow, M. (1978). The effects of dietary carbohydrate content on insulin binding and glucose metabolism in isolated rat adipocytes. Endocrinology 103, 2252-2263.

Poitier De Courcy, G., Durand, G., Abrahami, J. \& Gueguen, L. (1987). Recommendations on the feeding conditions of the laboratory animals (Rats and Mice). Sciences des Aliments 9, 209-217.

Reiser, S. \& Hallfrisch, J. (1977). Insulin sensitivity and adipose tissue weight of rats fed starch or sucrose diets ad libitum or in meals. Journal of Nutrition 107, 147-155.

Rizkalla, S. W., Baigts, F., Fumeron, F., Rabillon, B., Bayn, P., Ktorza, A., Spielmann, D. \& Apfelbaum, M. (1986). Comparative effects of several simple carbohydrates on erythrocyte insulin receptors in obese subjects. Pharmacology, Biochemistry and Behaviour 25, 681-688.

Rizkalla, S. W., Hellal, I., Boillot, J., Fontvieille, A. M., Laromiguière, M., Desplanque, N., Bruzzo, F., Tchobroutsky, G. \& Slama, G. (1990). Comparative metabolic effects of 10 week feeding of starch, glucose, fructose in normal rats. In Insulin and the Cell Membrane, pp. 443-450 [I. Klimes, B. V. Howard and C. R. Kahn, editors]. New York: Gordon \& Breach, Science Publishers, Inc.

Rodbell, M. (1964). Metabolism of isolated fat cells. 1. Effects of hormones on glucose metabolism and lipolysis. Journal of Biological Chemistry 239, 375-380.

Scatchard, G. (1949). The attraction of proteins for small molecules and ions. Annals of the New York Academy of Sciences 51, 660-672.

Schallenberger, R. S. (1963). Hydrogen bonding and the varying sweetness of the sugar. Journal of Food Science 28, 584-589.

Sheorain, V.S., Mattock, M. B. \& Subrahmanyam, D. (1980). Mechanism of carbohydrate-induced hypertriglyceridemia: plasma lipid metabolism in mice. Metabolism 29, 924-929.

Sleder, J., Chen, Y. D. I., Cully, M. D. \& Reaven, G. M. (1980). Hyperinsulinemia in fructose-induced hypertriglyceridemia in the rats. Metabolism 29, 303-305.

Taylor, S. A., Cattel, V. C., Pacy, J. \& Price, R. G. (1985). Changes in glomerular morphology in rats fed fructose diets-similarity to diabetic microangiopathy. Diabetic Medicine 2, 302a.

Taylor, S. A., Price, R. G., Kang, S. S. \& Yudkin, J. (1980). Modification of the glomerular basement membrane in sucrose-fed and streptozotocin-diabetic rats. Diabetologia 19,64-372.

Thomopoulos, P., Kosmakos, F. C., Pastan, I, \& Lovelace, E. (1977). Cyclic AMP increases the concentration of insulin receptors in cultured fibroblasts and lymphocytes. Biochemical and Biophysical Research Communications $75,246-251$.

Thorburn, A. W., Crapo, P. A., Beltz, W. F., Wallace, P., Witztum, J. L. \& Henry, R. R. (1989a). Lipid metabolism in non-insulin-dependent diabetes: effects of long-term treatment with fructose-supplemented mixed meals. American Journal of Clinical Nutrition 50, 1015-1022.

Thorburn, A. W., Storlien, L. H., Jenkins, A. B., Khouri, S. \& Kraegen, E. W. (1989 b). Fructose-induced in vivo insulin resistance and elevated plasma triglyceride levels in rats. American Journal of Clinical Nutrition 49, $1155-1163$.

Trischitta, V., Vigneri, R., Roth, R. A. \& Goldfine, I. D. (1984). ATP and other nucleoside triphosphates inhibit the binding of insulin to its receptor. Metabolism 33, 577-581.

Vrana, A., Fabry, P. \& Kazdova, L. (1976). Effects of dietary fructose on serum triglyceride concentrations in the rat. Nutrition Reports International 14, 593-596.

Zavaroni, I., Chen, Y.-D. I. \& Reaven, G. M. (1982). Studies of the mechanism of fructose-induced hypertriglyceridemia in the rat. Metabolism 31, 1077-1083. 